\title{
Kapasitas Komunitas Satuan Tugas Perlindungan Anak Terpadu Berbasis Masyarakat dalam Upaya Mewujudkan Kabupaten Pringsewu Layak Anak
}

\author{
Ita Prihantika ${ }^{* *}$; Ani Agus Puspawati²
}

Published online: 22 Desember 2021

\begin{abstract}
Tulisan ini bertujuan untuk mengurai kapasitas komunitas melalui variabel karakteristik komunitas, level agen sosial yang terlibat, fungsi-fungsi yang dijalankan, strategi yang digunakan, kondisi yang mempengaruhi komunitas dan berbagai macam dampak/luaran lainnya. Berdasarkan hasil penelitian, keadaan lingkungan awal terbentuknya komunitas Satgas PATBM memiki rasa kebersamaan dan komitmen untuk bekerja bersama yang cukup tinggi. Namun, kemampuan untuk menyelesaikan masalah dan mengakses berbagai sumberdaya yang ada di sekitar lingkungan dapat dikatakan belum maksimal. Hal ini dikonfirmasi dengan berbagai macam kelemahan/kekurangan yang dirasakan para anggota Satgas, yaitu kurangnya sumber daya finansial dan dukungan aparat Pekon setempat. Sejauh ini, strategi kepemimpinan dapat dikatakan efektif untuk meningkatkan kapasitas komunitas. Didukung oleh lingkungan cenderung tidak cepat berbubah, maka secara positif memberikan dampak kohesi sosial di masyarakat dan satgas itu sendiri. Secara umum, dampak dari kapasitas komunitas Satgas PATBM yang secara signifikan dirasakan oleh masyarakat adalah adanya peningkatan pelayanan sosial -yaitu perlindungan anak, yang lebih baik.
\end{abstract}

Keyword: Characteristic of Community; Level of Social Agency; Perlindungan Anak; Satgas PATBM

\section{Introduction}

Kekerasan membawa dampak negatif terhadap perkembangan anak (Tomlinson, dkk., 2013; Noviani, 2015; Coogan dkk., 2016; Dewi, dkk., 2019). Kekerasan ini menimbulkan rasa tidak aman, sedangkan rasa aman merupakan hak dasar anak yang harus dipenuhi (Huripah, 2014) yang wajib diberikan oleh pemegang kekuasaan di daerah tersebut (Khoiriah, dkk., 2019). Data yang dimiliki LaDA-DAMAR periode Januari - Agustus 2019, Kabupaten Pringsewu menempati urutan teratas tindak kekerasan pada anak di Provinsi Lampung (lihat tabel 1).

Tingginya kekerasan terhadap anak di Kabupaten Pringsewu bukan berarti bahwa Pemerintah Kabupaten dan

1. Jurusan Administrasi Negara, Universitas Lampung

2. Jurusan Administrasi Negara, Universitas Lampung

\section{*) corresponding author}

Ita Prihantika

Jl. Soemantri Brojonegoro No. 1, Kampus FISIP Univeristas Lampung, Kota Bandarlampung, Indonesia,

Telp./fax: 0721-2321132/0405-2324028

Email: itaprihantika@fisip.unila.ac.id masyarakat lalai terhadap perlindungan akan hak-hak anak. Prihantika dan Khoiriah (2019) dalam penelitiannya menemukan korelasi positif antara status Kabupaten Pringsewu sebagai Kabupaten Layak Anak (peringkat Pratama) dengan terungkapnya angka kekerasan/pelecehan dan pelanggaran-pelanggaran hak anak yang terjadi di Kabupaten tersebut.

Tabel 1. Kasus kekerasan periode Januari - Agustus 2019

\begin{tabular}{clcc}
\hline NO & Jenis Kekerasan & $\begin{array}{c}\text { Jumlah } \\
\text { Kasus }\end{array}$ & Persentase \\
\hline 1. & Perkosaan & 11 & 29,72 \\
\hline 2. & $\begin{array}{l}\text { Incest(hubungan } \\
\text { seks sedarah) }\end{array}$ & 5 & 13,51 \\
\hline 3. & Pencabulan & 5 & 13,51 \\
\hline 4. & Sodomi & 2 & 5,4 \\
\hline 5. & $\begin{array}{l}\text { Trafficking anak } \\
\text { untuk tujuan seksual }\end{array}$ & 1 & 2,7 \\
\hline \multicolumn{4}{c}{ TOTAL } \\
\hline
\end{tabular}

Sumber: Markhamah, 2019.

Sebagai salah satu kabupaten yang telah menggagas Kabupaten Layak Anak (sejak 2012) Pemerintah Kabupaten, aparat penegak hukum, aparat desa, masyarakat dan telah 
familiar dengan berbagai istilah dan konsep-konsep perlindungan anak. Terungkapnya kasus dan peristiwa kekerasan terhadap anak sehingga berlanjut ke ranah hukum dan mendapat ekspos media dapat dimaknai positif bahwa masyarakat Kabupaten Pringsewu menempatkan persoalan perlindungan dan kekerasan anak sebagai urusan publik dan bukan merupakan urusan domestik rumah tangga. Sehingga, kejadian pelanggaran terhadap hak-hak anak langsung direspon sebagai masalah bersama dan diselesaikan melalui jalur hukum.

Khusus di Kabupaten Pringsewu, sejak tahun 2012 telah tumbuh inisiatif pembentukan Sekolah Ramah Anak yang digagas oleh lembaga swadaya lokal L-PAMAS (Sulistiowati, dkk., 2017a dan 2017b). Adanya pembentukan Sekolah Ramah Anak ini kemudian merangsang kepekaan masyarakat ke berbagai gerakan ramah anak lainnya semisal Forum Anak, Kecamatan Layak Anak, Desa Layak Anak, Puskesmas Ramah Anak, Sekolah Ramah Anak, kelompok Perlindungan Anak Terpadu Berbasis Masyrakat (PATBM) Pekon, Pusat Kreativitas Anak Pekon dan Panti Asuhan (Apollonia, 2019).

Kabupaten Layak Anak merupakan komitmen seluruh stakeholder terutama pada tingkat tingkat grassroot/akar rumput, di mana untuk konteks penyelenggaraan Sekolah Ramah Anak peran L-PAMAS cukup siginifkan dalam menginisiasi, mengawal dan mendampingi keberlangsungan program ini (Sulistiowati, dkk., 2017a). Pada level non formal, terbentuk Satuan Tugas Perlindungan Anak Terpadu Berbasis Masyarakat (Satgas PA-TBM) yang secara signifikan juga berperan dalam memberikan edukasi, sosialisasi dan menjadi jembatan komunikasi serta memberikan pendampingan pada kasus-kasus kekerasan anak yang terjadi di lingkungan rukun tetangga (Prihantika dan Khoiriah, 2019; Saputra, 2018; Mulyani, dkk., 2017a, Mulyani, dkk., 2017b). Keberadaan Satgas PA-TBM ini menjadi semacam pengisi celah belum optimalnya implementasi kebijakan Kabupaten Layak Anak (Sulistiowati, dkk., 2018).

PATBM adalah sebuah gerakan dari jaringan atau kelompok warga pada tingkat masyarakat yang bekerja secara terkoordinasi untuk mencapai tujuan perlindungan anak. PATBM merupakan inisiatif masyarakat sebagai ujung tombak untuk melakukan upaya-upaya pencegahan dengan membangun kesadaran masyarakat agar terjadi perubahan pemahaman, sikap dan prilaku yang memberikan perlindungan kepada anak (Kemen PPA, 2016). PATBM ini merupakan mitra kerja yang penting bagi PP \& PA guna membentuk satgas yang ada di desa-desa (Tohamaksun, 2019).

Sebagai sebuah gerakan/lembaga, PATBM perlu mendapatkan sentuhan peningkatan kapasitas individu maupun organisasi. Aurina (2018) menemukan bahwa intervensi peningkatan kapasitas kelembagaan pada organisasi semacam ini sangat berguna bagi optimalisasi peran organisasi tersebut. Bintari dan Akbar (2017) menunjukkan para penggiat PA-TBM dan perlindungan anak lainnya sangat antusias pada program-program peningkatan kapasitas diri dan lembaga. Karena statusnya bukan merupakan perangkat pemerintahan maka menjadi pertanyaan selanjutnya tentang peningkatan kapasitas organisasi ini dari waktu ke waktu. Kekhawatiran ini juga diungkapkan oleh Kepala Bidang Perlindungan Anak dan Perempuan Dinas P3A - P2KB Kabupaten Pringsewu saat tim melakukan pra riset (Oktober, 2019). Sebab gerakan PA-TBM sifatnya sukarela tanpa ada imbalan materiil yang didapat oleh kader/penggeraknya. Secara khusus, Sari, dkk., (2018) mengungkapakan bahwa implementasi PATBM mengalami kekurangan sumber daya (baik manusia maupun finansial). Sejalan dengan penelitian-penelitian terdahulu (Aurina,
2018; Bintari dan Akbar, 2017; Mashitoh, 2018; Mubarok, 2010; Dwiyanto dan Jemadi, 2013) bahwa soal peningkatan kapasitas komunitas penggerak ini masih harus terus dilakukan, maka penelitian tentang kapasitas komunitas (community capacity) Satgas PA-TBM di Kabupaten Pringsewu juga perlu dilakukan dalam rangka menemukenali variabel-variabel kunci dalam keberlangsungan lembaga-lembaga akar rumput yang mendukung pelaksanaan kebijakan pemerintah daerah. Chaskin et al., (2001) mengatakan bahwa membangun kapasitas komunitas berarti bekerja untuk menguatkan dan meningkatkan komunitas miskin; bagaimana memperbaiki dan membangun kemampuan kolektif komunitas untuk berbagi masalah dan memanfaatkan peluang untuk meningkatkan kapasitas komunitas.

Penelitian tentang kebijakan kabupaten layak anak di Kabupaten Pringsewu dari berbagai macam perspektif telah banyak dilakukan (Sulistiowati, dkk., 2017a; Sulistiowati, dkk., 2017b; Sulistiowati, dkk., 2018; Prihantika dan Khoiriah, 2019; Atika, dkk., 2019). Dari penelitian tersebut menyimpulkan bahwa ada kontribusi yang cukup signifikan dari komunitas dan masyarakat dalam mendukung berjalannya kebijakan ini. Satuan Tugas PA-TBM sebagai gerakan yang berasal dari masyarakat dapat dipandang sebagai sebuah gerakan pemberdayaan masyarakat non ekonomi yang secara ilmiah cukup menarik untuk diteliti. Oleh karena itu penelitian ini akan berkontribusi dalam mengidentifikasi dimensi-dimensi kerangka hubungan capacity community dan capacity building pada Satuan Tugas Perlindungan Anak Terpadu Berbasis Masyarakat di Kabupaten Pringsewu dalam perspektif pemberdayaan masyarakat.

\section{Method}

Desain penelitian ini digunakan dalam penelitian ini yaitu pendekatan kualitatif deskriptif. Sebab penelitian berupaya menggambarkan sebuah fenomena atau kejadian dengan apa yang sebenarnya terjadi dan apa adanya. Lokasi penelitian di Kabupaten Pringsewu, dengan teknik purposive sampling informan yang dipilih adalah para ketua dan anggota Satuan Tugas PATBM di beberapa lokasi yaitu: Pekon Mataram, Pekon Waringin Sari Barat, Pekon Panggungrejo, Pekon Panggungrejo Utara, Pekon Sukoyoso, Pekon Sidodadi. Teknik pengumpulan data menggunakan pedoman wawancara terstruktur, observasi dan studi dokumentasi. Validasi data menggunakan teknik trianggulasi

\section{Results and Discussion}

Gerakan perlindungan anak terpadu berbasis masyarakat (PATBM) merupakan hasil kajian yang dilakukan oleh Kementerian Pemberdayaan Perempuan dan Perlindungan Anak pada tahun 2015 dengan mengambil lokasi di empat provinsi di Indonesia. Hasil penelitian tersebut merekomendasikan sebuah gerakan perlindungan anak yang lebih dekat dan berasal dari masyarakat setempat mendampingi program dan gerakan yang telah ada sebelumnya, misalnya Sekolah Ramah Anak, Forum Anak, dan Desa Layak Anak (Kemen PP-PA, 2016).

Merespon rekomendasi penelitian tersebut, Kementerian Pemberdayaan Perempuan dan Perlindungan Anakpada tahun 2016 mengeluarkan Pedoman Perlindungan Anak Terpadu Berabasis Masyarakat. Dalam 
buku pedoman tersebut yang dimaksud dengan Perlindungan Anak Terpadu Berbasis Masyarakat adalah sebuah gerakan dari jaringan atau kelompok warga pada tingkat masyarakat yang bekerja secara terkoordinasi untuk mencapai tujuan perlindungan anak. PATBM merupakan inisiatif masyarakat sebagai ujung tombak untuk melakukan upaya-upaya pencegahan dengan membangun kesadaran masyarakat agar terjadi perubahan pemahaman, sikap dan prilaku yang memberikan perlindungan kepada anak. Gerakan tersebut dapat dikelola dengan menggunakan dan mengembangkan fungsi struktur kelembagaan yang sudah ada atau jika diperlukan dengan membangun struktur kelembagaan baru (Kemen PP-PA, 2016).

Konsep "terpadu" dimaksudnya sebagai pemahaman tentang kesatuan semua aspek dan komponen kegiatan perlindungan anak yang dilakukan oleh berbagai unsur masyarakat dengan mensinergikan berbagai sumber tersedia (secara terkoordinasi). Kegaiatan terpadu harus memiliki tujuan yang bersifat luas sebagai sebuah kontinum yaitu mulai dari promosi hak anak, pencegahan., deteksi dan penanganan sejak dini hingga yang kompleks dengan melakukan perubahan-perubahan secara menyeluruh terhadap masyarakat, keluarga, dan anak. Untuk menghilangkan/mengurangi faktor-faktor penyebab permasalahan dan risiko- risiko kekerasan terhadap anak yang telah atau mungkin terjadi, baik pada anak, keluarga, masyarakat. Konsep "terpadu" juga mengandung makna mendayagunakan berbagai sumber daya secara optimal, termasuk melibatkan berbagai unsur masyarakat, mensinerginakan dukungan sumber daya masyarakat, pemerintah, dan dunia usaha.

Sedangkan konsep "berbasis masyarakat" dimaksudnya sebagai upaya yang memberdayakan kapasitas masyarakat untuk dapat mengenali, menelaah, dan mengambil inisiatif dalam mencegah dan memecahkan permasalahan yang ada secara mandiri. Masyarakat yang dimaksud dalam konteks gerakan ini adalah komunitas (kelompok orang yang saling berinteraksi) yang tinggal di suatu batas-batas administrasi pemerintahan yang paling kecil, yaitu desa/kelurahan.

Pada hampir semua Satuan Tugas Perlindungan Anak Terpadu Berbasis Masyarakat yang diwawancarai mengaku pembentukan Satgas PATBM ini merupakan hasil inisiasi awal oleh lembaga/organisasi luar, yaitu L-PAMAS dan LDA yang keduanya merupakan perpanjangan tangan lembaga yang berasal dari Amerika Serikat yaitu Child Funds. Meski diinisiasi awal oleh lembaga di luar komunitas, namun lambat laun Satgas PATBM ini mampu secara mandiri mengurus dirinya dan menjalankan berbagai macam tugas pokok dan fungsi seperti amanat Kementerian Pemberdayaan Perempuan dan Perlindungan Anak (Kemen PP-PA) dalam buku Pedoman Perlindungan Anak Terpadu Berabasis Masyarakat 2016.

Peneliti menggunakan kerangka hubungan kapasitas komunitas dan pengembangan kapasitas yang dikembangkan oleh Chaskin et al (2001) dan bermaksud menggambarkan dinamika hubungan antara variabel tersebut pada Satuan Tugas Perlindungan Anak Terpadu Berbasis Masyarakat (PATBM) di Kabupaten Pringsewu.

\section{Gambar 1. Hubungan community capacity dan capacity building}

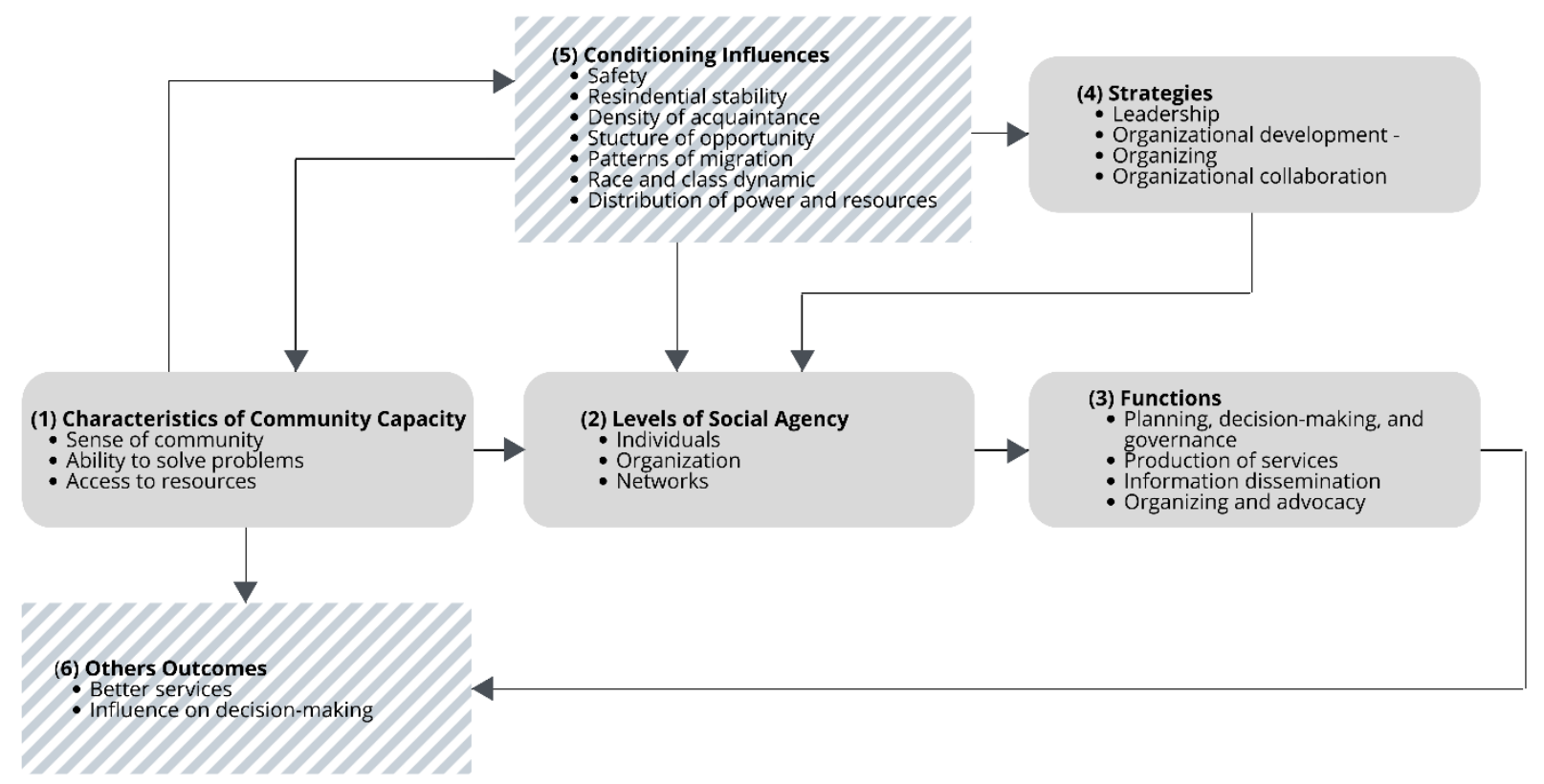

Sumber: Chaskin et al., 2001

\section{Karakteristik kapasitas komunitas}

Komunitas yang baik harus memiliki komitmen bersama dalam menjalankan aktivitas organisasinya. Komitmen bersama dari seluruh pengurus dan anggota organisasi merupakan modal dasar yang harus terus menerus ditumbuhkembangkan dan dipelihara secara baik. Komitmen bersama tidak hanya di kalangan yang menjabat ditingkat pimpinan dan jabatan tertentu, namun harus dimiliki oleh semua anggota organisasi. Komitmen bersama menjadi dasar untuk penyusunan rancangan kegiatan yang partisipatif, sehingga dapat dilaksanakan secara bersamasama.

Menurut (Chaskin et al., 2001) bahwa setiap komunitas punya karakteristik yang berbeda-beda, namun setidaknya memiliki rasa kebersamaan, komitmen, kemampuan untuk mengakses masalah dan akses terhadap sumber daya. Konfirmasi di lapangan menemukan seluruh informan memandang bahwa rasa kebersamaan di komunitas sangat kuat, dan diwujudkan dengan kesediaan beberapa anggota untuk kemudian bersedia berkomitmen membagi tanggung jawab untuk menjadi satuan tugas perlindungan anak. 
Karaktetistik lain adalah kemampuan untuk mengakses masalah, yang diwujudkan melalui kemampuan untuk menterjemahkan komitmen ke aksi (akan berubah sering dengan perkembangan komunitas). Setelah mampu mengakses masalah, kemudian komunitas juga mampu mengakses sumber daya. Sumber daya yang diakes Pada hampir seluruh informan, diperoleh pernyataan bahwa karakteristik komunitas (dalam hal ini diwakili oleh masyrakat lingkup Pekon (Desa/Kelurahan) hamper memiliki ciri-ciri yang disebutkan oleh Chaskin et al (2001). Dengan demikian, Satgas PATBM sebagai sebuah gerakan kemasyarakatan mendapatkan media yang pas untuk dapat berkembang sebagai sebuah gerakan dari warga untuk warga.

Pada sebagian besar informan ditemukan bahwa karakteristik komunitas (dalam hal ini diwakili oleh masyarakat lingkup Pekon (Desa/Kelurahan) hampir memiliki ciri-ciri yang disebutkan oleh Chaskin et al (2001). Dengan demikian, Satgas PATBM sebagai sebuah gerakan kemasyarakatan mendapatkan media yang pas untuk dapat berkembang sebagai sebuah gerakan dari warga untuk warga.

\section{Level agensi sosial}

Level agensi sosial diterjemahkan sebagai tingkatan (individu, organisasi, dan jejaring) serta intervensi yang dapat mereka lakukan terhadap komunitas yang terbentuk. Temuan di lapangan menunjukkan bahwa agen sosial yang cukup berpengaruh pada komunitas ini adalah individu dan organisasi. Individu sangat berperan dalam keberlangsungan komunitas Satgas PATBM, yaitu Ketua Satgas. Mengapa individu ini sangat berpengaruh? Sebab organisasi ini beranggotakan individu-individu yang berpartisipasi secara sukarela tanpa imbalan. Sehingga, ketua kelompok berpengaruh besar untuk menggerakkan dan mengkoordinir berbagai macam kegiatan komunitas. Menurut pengakuan beberapa informan, ketika menangani sebuah kasus kekerasan terhadap anak di lingkup kerja Satgas PATBM yang mereka pimpin, Ketua Satgas PATBM ini terkadang membiayai sendiri berbagai keperluan untuk pendampingan tersebut.

\section{Fungsi komunitas}

Fungsi komunitas berbeda-beda tergantung dengan kebutuhan yang diperlukan oleh komunitas. Pada komunitas yang kuat akan terbentuk fungsi yang kuat (perform normative fungtions) maka fungsi normatif akan berjalan secara kuat dan mendalam misalnya hal-hal kecil akan berjalan dengan sendirinya dan tanpa Pengawasan. Sedangkan pada komunitas yang lemah maka akan terjadi sebaliknya. Fungsi normatif akan berjalan ketika mendapat perhatian bersama, misalnya pengadaan taman bermain atau ruang terbuka menjadi kepentingan bersama. Fungsi normatif ini akan lebih memilih untuk mengembangkan sebuah mekanisme baru mereka lebih fokus pada hal-hal yang kecil.

Temuan data lapangan mengidentifikasi beberapa fungsi komunitas Satgas PATBM yang telah dan sedang dijalankan, yaitu fungsi perencanaan, pengambilan keputusan, tata kelola komunitas, penyebaran informasi serta pengorganisasian dan advokasi. Fungsi perencanaan dilakukan pada tahap awal pembentukan komunitas Satgas
PATBM. Dalam waktu berjalan, komunitas ini juga menyepakati perencanaan-perencaaan baru sesuai dengan perkembangan keadaan. Satgas PATBM merumuskan visi, misi, program kerja, dan berbagai macam kegiatan yang mereka jalankan dalam kurun waktu tertentu. Pengakuan beberapa informan juga menyebutkan bahwa pada perjalanan waktu, terdapat berbagai macam kendala, sehingga tidak semua perencanaan yang telah mereka canangkan berhasil dengan baik.

Fungsi pengambilan keputusan dilakukan secara kolektif kolegial, artinya meski Ketua Satgas PATBM memiliki hak untuk memutuskan terhadap sebuah kasus/kejadian, namun Ketua Satgas tetap berkoordinasi dan meminta pendapat anggotanya. Hal ini dapat dimengerti, dikarenakan Satgas PATBM ini bukan merupakan komunitas yang besar, anggotanya berkisar 10 30 orang saja dengan sifat keanggotaan sukarela.

Fungsi tata kelola komunitas masih berjalan dengan sederhana. Dikarenakan sifat organisasi ini sukarela, sehingga tata kelola yang dipraktekkan juga masih sederhana. Secara fisik, setiap Satgas memiliki sekretariat di masing-masing kantor pekon, namun untuk pertemuan bulanan atau rapat rutin, anggota satgas lebih memilih berpindah dari satu rumah anggota ke rumah yang lain. Sebagai sebuah organisasi, kantor sebagai tempat pusat kegiatan organisasi belum tersedia.

Fungsi penyebaran informasi dilakukan oleh setiap anggota satgas, baik yang sifatnya internal maupun eksternal. Penyebaran informasi internal dilakukan melalui aplikasi sosial media whatsapp meski ada beberapa anggota yang tidak memiliki gawai, maka informasi yang diterima oleh satgas akan langsung disampaikan secara tatap muka. Sedangkan penyebaran informasi yang sifatnya eksternal, dilakukan dengan meneruskan informasi yang sifatnya edukasi ataupun berita kepada masyarakat pekon, baik melalui aplikasi sosial media whatsapp maupun secara tatap muka.

Fungsi pengorganisasian dan advokasi dilakukan jika terjadi peristiwa atau kasus kekerasan yang melibatkan anak (baik sebagai korban maupun sebagai pelaku). Hampir seluruh satgas yang menjadi informan penelitian ini, sudah pernah melakukan pengorganisasian dan advokasi kasus perlindungan anak di pekon masing-masing. Dimulai dari persiapan aksi, aksi dan diakhiri dengan evaluasi.

\section{Strategi}

Strategi adalah salah satu cara untuk mencapai tujuan dan sasaran organisasi yang telah direncanakan sebelumnya. Rencana yang dirumuskan secara sistemik oleh sebuah organisasi baik publik maupun swasta yang dijadikan sebagai langkah-langkah terarah dan berorentasi pada jangka panjang agar tujuan dalam organisasi tersebut dapat tercapai. Strategi pada komunitas yang bekerja dengan baik, ke empat elemen (kepemimpinan, pengembangan organisasi, pengorganisasian, kolaborasi organisasi) dilaksanakan dengan optimal.

Temuan lapangan pada hampir seluruh satgas menunjukkan kepemimpinan merupakan faktor yang cukup signifikan dalam perjalanan tumbuh kembang Satgas PATMB. Sebagai sebuah entitas sosial yang dibentuk secara 
sukarela, peran kepemimpinan untuk memberi arahan, motivasi dan pendampingan praktis dalam penanganan kasus maupun keberlangsungan rutinitas organisasi. Selain strategi Kepemimpinan, pengembangan organisasi juga dilakukan melalui proses diskusi, rapat, pemecahan masalah bersama, dan kerja sama dalam penanganan kasus. Strategi pengembangan organisasi dilakukan dengan bentuk yang masih sederhana, yaitu mengikuti pelatihan yang sifatnya undangan. Satgas PATBM tidak memiliki anggaran yang cukup untuk bisa mengakses pelatihan yang berbayar. Bentuk pengembangan organisasi yang dilakukan adalah berbagi ilmu dan diskusi antar anggota atau interaksi dengan stakeholder.

\section{Kondisi yang Berpengaruh}

Kondisi lingkungan sekitar juga sangat berpengaruh terhadap keberlangsungan dan pengembangan kapasitas komunitas. Kondisi yang mempengaruhi adalah suatu keadaan yang dapat mempengaruhi eksistensi sebuah komunitas untuk berkembang atau akan menjadi lemah, yaitu keamanan, stabilitias pemukiman/tempat tinggal, jenis pengetahuan, struktur peluang, pola migrasi, dinamika dan kecepatan perubahan kelas sosial, serta distribusi kekuasaan da sumber daya.

Kondisi eksternal Satgas PATBM di Kabupaten Pringsewu memiliki pengaruh yang relative stabil. Perubahan-perubahan sosial di Pekon tidak cepat dan dinamis. Masyarakat Pekon cenderung stagnan. Namun kondisi ini bisa dipandang sebagai faktor penguat kohesi sosial inter anggota satgas maupun antar anggota satgas dan masyarakat Pekon. Kohesi sosial yang kuat akan mendorong masyarakat untuk nyaman, membuka diri dan berpartisipasi dalam upaya perlindungan anak.

\section{Dampak}

Eksistensi komunitas juga akan menghasilkan dampakdampak luaran yang secara sadar atau tidak sadar terbentuk secara alami. Fungsi dari komunitas akan membaca pada dua kemungkinan akhir, yang pertama adalah peningkatan keberlangsungan kapasitas komunitas secara umum. Jika dijelaskan dalam bagan tersaji maka karakteristik spesifik pada komunitas yang dijabarkan dalam point pertama yang berhubunan dengan level sosial agen pada point nomor 2 dapat mendoromg performa fungsi khusus pada point $\mathrm{C}$ dan mencapai tujuan yang seharusnya dicapai komunitas pada point nomor F ini. Keberadaan komunitas Satgas PATBM ini memiliki dampak pada pelayanan yang lebih baik, terutama pada aspek perlindungan anak dari tindakan kekerasan.

Kapasitas komunitas dapat diurai melalui variabel karakteristik dari kapasitas komunitas, level agen sosial yang terlibat, fungsi-fungsi yang dijalankan, strategi yang digunakan, kondisi yang mempengaruhi komunitas dan berbagai macam dampak/luaran lainnya. Berdasarkan hasil penelitian, keadaan lingkungan awal terbentuknya komunitas Satgas PATBM memiki rasa kebersamaan dan komitmen untuk bekerja bersama yang cukup tinggi. Namun, kemampuan untuk menyelesaikan masalah dan mengakses berbagai sumberdaya yang ada di sekitar lingkungan dapat dikatakan belum maksimal. Hal ini dikonfirmasi dengan berbagai macam kelemahan/kekurangan yang dirasakan para anggota Satgas, yaitu kurangnya sumber daya finansial dan dukungan aparat Pekon setempat. Sejauh ini, strategi kepemimpinan dapat dikatakan efektif untuk meningkatkan kapasitas komunitas. Didukung oleh lingkungan cenderung tidak cepat berbubah, maka secara positif memberikan dampak kohesi sosial di masyarakat dan satgas itu sendiri. Secara umum, dampak dari kapasitas komunitas Satgas PATBM yang secara signifikan dirasakan oleh masyarakat adalah adanya peningkatan pelayanan sosial -yaitu perlindungan anak, yang lebih baik.

\section{Conclusions and Recommendations}

Hasil penelitian mengkonfirmasi sebagian dari kerangka kapasitas komunitas yang dicetuskan oleh Chaskin et al., (2001) Penelitian ini memiliki keterbatasan untuk dapat digenerlisasi kepada seluruh anggota komunitas Satgas PATBM yang ada di Kabupaten Pringsewu atau Indonesia. Di masa mendatang, penelitian bisa membuat pemodelan sosial dan kontribusi Pemerintah Daerah untuk membangun kapasitas komunitas Satgas PATBM di Kabupaten Pringsewu secara khusus, dan di Indonesia secara umum.

\section{Acknowledgements}

Tim peneliti mengucapkan terimakasih kepada Lembaga Penelitian dan Pengabdian Masyarakat Universitas Lampung yang telah mendanai penelitian ini melalui Hibah Penelitian Dosen Pemula pada Tahun Anggaran 2020.

\section{Conflict of Interests}

Para penulis menyatakan bahwa tidak ada potensi konflik kepentingan sehubungan dengan kepengarangan dan publikasi artikel ini.

\section{References}

Apollonia, A. (2019). Targetkan sebagai Kabupaten Layak Anak Tahun 2019, Tim Verifikasi Kunjungi Pringsewu. Website resmi Kabputena Pringsewu diakses pada https://kb.pringsewukab.go.id/targetkansebagaikabupaten-layak-anak-tahun-2019-tim- verifikasikunjungi-pringsewu/ pada tanggal 19 Februari 2020 pukul 03:15 WIB

Atika, D.B., Prihantika, I., dan Puspawati, A. A. (2019). Partisipasi Komunitas Menuju Pekon Layak Anak (Dokumen Laporan Pengabdian kepada Masyarakat). Bandarlampung: LP3M Universitas Lampung (tidak diterbitkan).

Aurina, R., Koswara, H., Susilowati, E. (2018). Pengembangan Kapastias Organisasi Lokal Bina Keluarga Remaja (BKR) Nusa Indah dalam Penanganan Kenakalan Remaja di Desa Cibiru Wetan Kecamatan Cileunyi Kabupaten Bandung. Peksos: Jurnal IImiah Pekerjaan Sosial, 172), $258-280$. 
Bintari, A., dan Akbar, I., (2017). PENINGKATAN PENGETAHUAN PERLINDUNGAN ANAK TERPADU BERBASIS MASYARAKAT (PATBM) DI KELURAHAN CIPAGERAN KOTA CIMAHI TAHUN 2017. Jurnal Pengabdian Kepada Masyarakat, 1(6), 387 - 391.

Chaskin, R. R., Brown, P., Venkatesh, S., \& Vidal, A. (2001). Building community capacity. New York: Aldine de Gruyter. https://doi.org/10.4324/9781315081892

Coogan, P.F., Wise, L.A., O’Connor, G.T., Brown, T.A., Palmer, J.R., and Rosenberg, L. (2012). Abuse during childhood and adolescence and risk of adult-onset asthma in African American women". J Allergy Clin Immunol, 131(4), 1058 1063. http://dx.doi.org/10.1016/i.jaci.2012.10.023

Dewi, M.S., Subardhini, M., Sundayani, Y. (2019). Kecemasan Anak Korban Tindak Kekerasan Seksual di Yayasan Rumah Aman Sumur Kabupaten Nganjuk. Peksos: Jurnal Ilmiah Pekerjaan Sosial, 18(2).

Dwiyanto, B., dan Jemadi, J. (2013). Pemberdayaan Masyarakat dan Pengembangan Kapasitas dalam Penanggulangan Kemiskinan melalui PNPM Mandiri Perkotaan. Jurnal Maksipreneur: Manajemen, Koperasi, dan Entrepreneurship, 3(1), 36-62. doi:http://dx.doi.org/10.30588/imp.v3i1.87

Huripah, E. (2014). Pemenuhan Hak Rasa Aman bagi Anak sebagai Implementasi Hak Anak. Jurnal IImiah Pekerjaan Sosial, 13(1).

Kementerian Pemberdayaan Perempuan dan Perlindungan Anak RI. (2016). Pedoman Perlindungan Anak Terpadu Berbasis Masyarakat (PATBM) Edisi 1. Jakarta: Kemen PPPA RI.

Khoiriah, S., Prihantika, I., dan Fatmawati, N. (2019). Penguatan Kebijakan Pemerintah Desa dalam Memberikan Perlindungan terhadap Anak (Dokumen Laporan Pengabdian kepada Masyarakat). Bandarlampung: LP3M Universitas Lampung (tidak diterbitkan).

Markhamah, S.S. (2019). LAdA-Damar Ungkap 31 Kasus Kekerasan Anak di Lampung, Terbanyak di Pringsewu. Tribunews Jumat 02 Agustus 2019. Diakses pada https://lampung.tribunnews.com/2019/08/02/ladadamar-ungkap-31-kasus-kekerasan-anak-dilampung-terbanyak-di-pringsewu?page=all tanggal 17 Februari 2020 pukul 06:43 WIB.

Mubarak, Z. (2010). Evaluasi Pemberdayaan Masyarakat Ditinjau dari Proses Pengembangan Kapasitas pada Kegiatan PNPM Mandiri Perkotaan Desa Sastrodirjan Kabupaten Pekalongan. Semarang: Universitas Diponegoro.

Mulyani, W., Winarni, T., Harsoyo, \& Nurhadi, N. (2017a). MODEL PENCEGAHAN DAN PENANGANAN KEKERASAN ANAK BERBASIS MASYARAKAT. Demography Journal Of Sriwijaya (DeJoS), 1(2), 36-45. Retrieved from http://ejournalpps.unsri.ac.id/index.php/dejos/article/view/29

Mulyani, W., Winarni, T., Harsoyo, \& Nurhadi, N. (2017b). Model Perlindungan Anak Berbasis Masyarakat.
Prosiding Seminar Nasional Kependudukan \& Kebijakan Publik Peran Kependudukan untuk Mempersiapkan Generasi Emas Menuju Sustainable Development Goals (SDG's). Aula Pascasarjana Universitas Sriwijaya Palembang 27 -28 September 2017.

Noviana, I. (2015). Kekerasan Seksual terhadap Anak: Dampak dan Penanganan Child Sexual Abuse: Impact and Healing" Socio Informa, 1(1), 13 - 28.

Prihantika, I., dan Khoiriah, S. (2019). Identifikasi Dynamic Capability (Dokumen Laporan Penelitian). Bandarlampung: LP3M Universitas Lampung (tidak diterbitkan).

Saputra, Q.E. (2018). Peran Perlindungan Anak Terpadu Berbasis Masyarakat (PATBM) Bandar Lampung Terhadap Anak Korban Kekerasan (Tesis). Fakultas Hukum: Universitas Lampung.

Sari, M., Wahyu, W., \& Achmad, B. A. (2018). Implementasi Program Perlindungan Anak Terpadu Berbasis Masyarakat di Kota Palangka Raya. Anterior Jurnal, $18(1)$, 48-56. https://doi.org/10.33084/anterior.v18i1.437

Sulistiowati, R., Atika, D. B., Prihantika, I. (2017a). CIVIL SOCIETYDALAM PROGRAM SEKOLAH RAMAH ANAK (SRA) UNTUK MENDUKUNG KEBIJAKAN KABUPATEN LAYAK ANAK (KLA). Seminar Nasional tentang "Membangun Etika Sosial Politik Menuju Masyarakat Yang Berkeadilan”, FISIP Universitas Lampung, 18 Oktober 2017 di Hotel Swiss, Bandar Lampung.

Sulistiowati, R., Atika, D.B., Prihantika, I., Melinda, S.D., 2017b. CHILD FRIENDLY SCHOOL AS THE FORM OF PUBLIC PARTICIPATION IN POLICY PROCESS". ICSTIEM 2017 tema "The Role of Information and Technological Innovation for Social and Economic Development in Emerging Countries", Bandar Lampung 27 Desember 2017, Universitas Sang Bumi Ruwai Jurai.

Sulistiowati, R., Prihantika, I., Atika, D.B., Sari, Y.R., 2018. Implementasi Kebijakan Kabupaten Layak Anak di Kabupaten Pringsewu. Spirit Publik, 13, (2), 37-46. Dapat diakses pada https://103.23.224.239/spiritpublik/article/view/24874.

Tohamaksun, M. (ed). (2019). Dinas PPPA Lampung Perkuat Perlindungan Anak Dengan Gerakan PATBM". Antara, Senin 08 April 2019. Diakses pada https://megapolitan.antaranews.com/berita/57377/ dinas-pppa-lampung-perkuat-perlindungan-anakdengan-gerakan-patbm tanggal 20 Februari 2010, Pkl. 16.08 WIB.

Tomlinson, M., Jordans, M., MacMillan, H., Betancourt, T., Hunt, X., dan Mikton, C. (2017). Research priority setting for integrated early child development and violence prevention $(E C D+)$ in low and middle income countries: An expert opinion exercise", Child

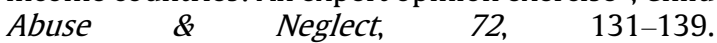
http://dx.doi.org/10.1016/i.chiabu.2017.07.021. 